\title{
Fournier's gangrene of scrotum in a patient with AIDS
}

\author{
M Murphy, M Buckley, J Corr, S Vinayagamoorthy, R Grainger, F M Mulcahy
}

\begin{abstract}
Fournier's gangrene of the scrotum, a form of necrotising fasciitis, is a rare but potentially fatal disorder. Predisposing conditions include chronic alcoholism and diabetes mellitus, possibly as a result of impaired immunity. Fournier's syndrome, occurring in a patient with AIDS, is described.
\end{abstract}

\section{Introduction}

Fournier, a French venereologist, described five cases of idiopathic gangrene of the scrotum in $1883 .{ }^{1}$ Whilst not identifying a specific aetiological agent, he observed that this disorder occurred more commonly in diabetic patients and could be precipitated by local trauma to the genitalia. Fournier's gangrene is now recognised to be a form of synergistic necrotising subcutaneous infection of the male genitalia leading to gangrene of overlying dermal tissues. ${ }^{2}$ We report the first case of Fournier's gangrene in an intravenous drug user with AIDS.

\section{Case report}

A 33 year old male intravenous drug user with AIDS was admitted with pyrexia and confusion. He was diagnosed HIV seropositive in 1986 and had histologically proven Pneumocystis carinii pneumonia (PCP) in August 1989. He was taking co-trimoxazole and fluconazole for prophylaxis of PCP and oral candida respectively. Zidovudine therapy had been discontinued two months previously because of recurrent anaemia. Prior to admission he had been injecting crushed morphine sulphate tablets (MST) into both femoral veins.

On examination, he was febrile $\left(38.5^{\circ} \mathrm{C}\right)$ and dehydrated. No obvious focus of infection was found apart from bilateral tender indurated needle tracts in the femoral regions. The external genitalia were normal. Laboratory investigations revealed renal

\footnotetext{
Department of Genitourinary Medicine

M Murphy, M Buckley, S Vinayagamoorthy, F M Mulcahy

Department of Urology

J Corr, R Grainger

St James's Hospital, Dublin 8, Eire
}

failure with urea of $33.8 \mathrm{mmol} / 1$ (normal 3-7) and creatinine of $443 \mu \mathrm{mol} / 1$ (50-125). Blood glucose 5 $\mathrm{mmol} / 1$ (3.5-6.5). Full blood count showed haemoglobin of $8 \cdot 1 \mathrm{~g} / \mathrm{dl}(13-18)$, total white cell count of $7.4 \times 10^{9} / 1(4-11)$ (granulocytes $96 \%$ ) and platelets of $108 \times 10^{9} / 1(150-400)$. Helper $\mathrm{T}$ cell count was $0.12 \times 10^{9} / 1(0 \cdot 39-1 \cdot 31)$. Blood cultures taken on admission subsequently isolated two diphtheroid species and a gram positive bacillus. All organisms were sensitive to penicillin. No organism was isolated from urine culture.

Intravenous fluids were commenced and the patient was catheterised with difficulty. At the time of catheterisation a tender swelling with crepitus of the right hemiscrotum was noted. The swelling and tenderness increased over the next 12 hours and in view of the possibility of urethral trauma urological advice was sought. Crepitus was again noted and the patient was commenced on intravenous benzyl penicillin. On the third day after admission patches of gangrene developed on the right hemiscrotum (fig 1). The patient was toxic and developed disseminated intravascular coagulation (DIC). Combination broad spectrum antimicrobial therapy was instituted with intravenous cefotaxime and metronidazole in addition to penicillin. Surgical debridement of the necrotic tissue was performed which involved excision of scrotum, proximal penile skin and subcutaneous tissues of lower abdominal wall from anterior superior iliac spine inferiorly to the anus with incision and drainage of a large ischiorectal abscess. The testes were normal and were left exposed (fig 2). Aerobic cultures of swabs from necrotic tissues isolated a streptococcus species, $E$ coli and Proteus mirabilis. Anaerobic cultures isolated a peptostreptococcus species.

Forty eight hours later the DIC had resolved, and renal function returned to normal. On the seventh postoperative day the patient became febrile. $S$ aureus and Candida albicans were isolated from peripheral venous and central venous catheter blood cultures. Despite replacement of the central venous catheter and treatment with intravenous flucloxacillin and fluconazole, the patient developed acute renal failure and expired 16 days following admission to hospital. Necropsy revealed disseminated candida infection involving the oesophagus, heart, kidneys, lungs, thyroid and groin debridement area. 


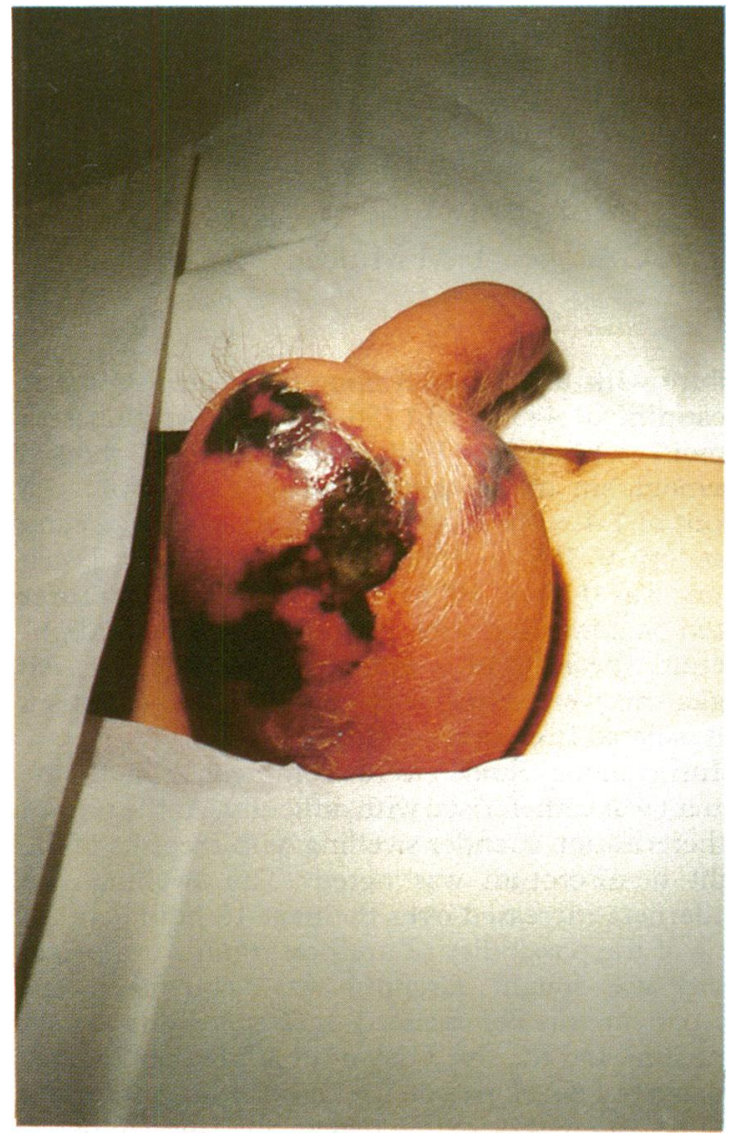

Figure 1 Fournier's gangrene of scrotum: swelling and patches of necrosis.

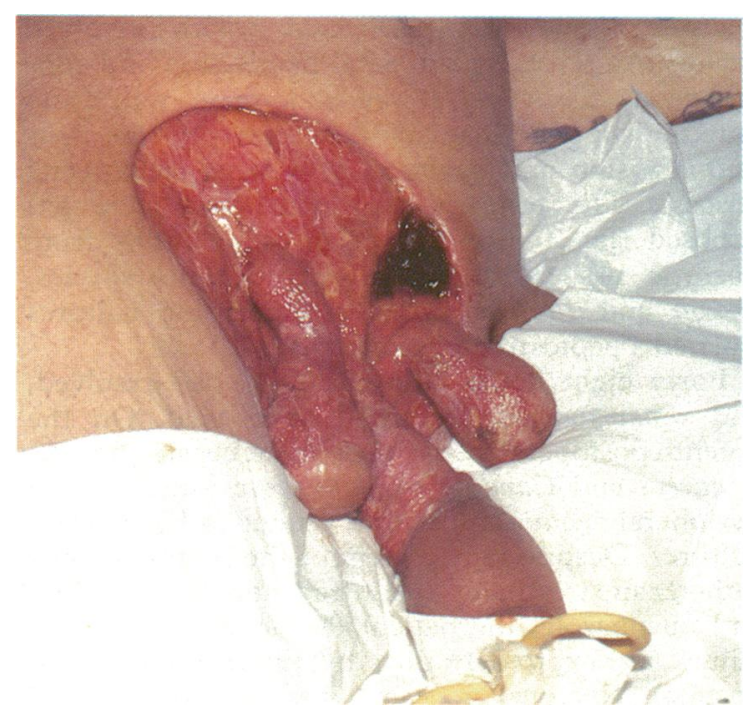

Figure 2 External genitalia following extensive surgical debridement of gangrenous tissue.

\section{Discussion}

Fournier's gangrene of the scrotum, a form of fulminant necrotising fasciitis, is caused by a synergistic polymicrobial bacterial infection of the subcutaneous tissues which rapidly spreads along the fascial planes. ${ }^{3}$ Obliterative endarteritis and subcutaneous vessel thrombosis leads to gangrene of the dermal tissues. ${ }^{4}$ The onset may be insidious and there is often a delay in diagnosis. ${ }^{3}$ Despite the use of broad spectrum antibiotics and radical debridement of necrotic tissue, mortality from this syndrome ranges from $13-45 \%$. $^{4-6}$

The majority of cases occur as a result of one of three mechanisms: (1) local trauma providing organisms access to the subcutaneous tissues, (2) extension of infection from the urinary tract, (3) extension of a perianal infection. ${ }^{5}$ Patients with debilitating illnesses such as chronic alcoholism and diabetes mellitus are particularly susceptible to this condition. ${ }^{46}$ The apparent predisposition of diabetic patients to Fournier's syndrome reflects their impaired immunity and increased susceptibility to bacterial infections. ${ }^{78}$

Patients with AIDS are also prone to bacterial infections which are an important cause of morbidity and mortality. In one series of necropsy cases, $83 \%$ had bacterial infections at some stage during the course of their illness. ${ }^{9}$ Community acquired bacterial pneumonia is a significant cause of hospital admission $^{1011}$ and, regardless of intravenous drug use, there appears to be an increased risk of Staphylococcus aureus bacteraemia/infections in this group. ${ }^{12}$ This propensity to bacterial infections is probably due to abnormalities of neutrophil and B-lymphocyte function ${ }^{1314}$ in addition to helper $T$-cell depletion and dysfunction.

In this case there were three potential sources of infection. Firstly, urethral catheterisation is a well recognised precipitating factor of this syndrome, with infection spreading from infected periurethral glands to the corpus spongiosum and subcutaneous tissues. ${ }^{5}$ However, this was unlikely in view of the fact that swelling, tenderness, and crepitus were noted at the time of catheterisation. Secondly, infection from the ischiorectal abscess may have spread along the fascial planes piercing Colles fascia to reach the penis and scrotum. Thirdly, by injecting into the groin, the patient may have provided organisms access to the subcutaneous tissues. Necrotising fasciitis occurring at other sites such as the limbs, is well recognised in intravenous drug users where the infection is introduced through a break in the skin either by subcutaneous or intravenous injection of illicit drugs. ${ }^{15}$

As far as we are aware, this is the first reported case of Fournier's gangrene occurring in a patient with AIDS. IVDUs with AIDS who inject into the femoral region may constitute another risk group for 
the development of Fournier's gangrene of the scrotum.

Address for correspondence: $\operatorname{Dr} M$ Murphy, Department of Genitourinary Medicine, Leeds General Infirmary, Blundell Street, Leeds LS1 3EX, UK.

1 Fournier AJ. Gangrene foudroyante de la verge. Sem Med 1883;3:345-8.

2 Rudolph R, Soloway M, DePalma RG, Persky L. Fournier's syndrome: synergistic gangrene of the scrotum. Am J Surg 1975;129:591-6.

3 Curtis Nickel J, Morales A. Necrotising fasciitis of the male genitalia (Fournier's gangrene). Can Med Assoc J 1983; 129:445-8.

4 Wolach MD, MacDermott JP, Stine AR, deVere White RW. Treatment and complications of Fournier's Gangrene. Br $J$ Urol 1989;64:310-4.

5 Jones RB, Hirschmann JV, Brown GS, Tremann JA. Fournier's syndrome: necrotising subcutaneous infection of the male genitalia. J Urol 1979;122:279-82.

6 Spirnak JP, Resnick MI, Hampel N, Persky L. Fournier's gangrene: report of 20 patients. $J$ Urol 1984;131:289-91.
7 Nolan CM, Beaty HN, Bagdade JD. Further characterisation of impaired bactericidal function of granulocytes in patients with poorly controlled diabetes. Diabetes 1978;27:889-94.

8 Rayfield EJ, Ault MJ, Keusch GT, Brothers MJ, Nechemias C, Smith $\mathrm{H}$. Infection and diabetes: the case for glucose control. Am J Med 1982;72:439-50.

9 Nichols L, Balogh K, Silverman M. Bacterial infections in the acquired immune deficiency syndrome. Clinicopathological correlations in a series of autopsy cases. Am J Clin Pathol 1990;92:787-90.

10 Selwyn PA, Feingold AR, Hartel D, et al. Increased risk of bacterial pneumonia in HIV-infected intravenous drug users without AIDS. AIDS 1988;2:267-72.

11 Polsky B, Gold JWM, Whimbey E, et al. Bacterial pneumonia in patients with the acquired immunodeficiency syndrome. $A n n$ Intern Med 1986;104:38-41.

12 Jacoboson MA, Gellermann $H$, Chambers $H$. Staphylococcus aureus bacteraemia and recurrent staphylococcal infection in patients with acquired immunodeficiency syndrome and AIDS-related complex. Am J Med 1988;85:172-6.

13 Ellis M, Gupta S, Galant S. Impaired neutrophil function in patients with AIDS or AIDS-related complex: a comprehensive evaluation. $J$ Inf Dis 1988;158:1268-75.

14 Lane HC, Masur H, Edgar LC, et al. Abnormalities of B-cell activation and immunoregulation in patients with the Acquired Immune Deficiency Syndrome. $N$ Engl J Med 1983;309:453-8.

15 Simmons RL Ahrenholz DH. Infections of the skin and the soft tissues. In: Simmons RK, Howard RJ, eds. Surgical Infectious Diseases. New York: Appleton-Century-Crofts, 1982.

Accepted for publication 27 March 1991 